\title{
Non-pollen palynomorphs notes: 2. Holocene record of Megalohypha aqua-dulces, its relation to the fossil form genus Fusiformisporites and association with lignicolous freshwater fungi
}

\author{
Lyudmila S. Shumilovskikh a,b,c,*, Astrid Ferrer ${ }^{\mathrm{d}}$, Frank Schlütz ${ }^{\mathrm{e}}$ \\ ${ }^{a}$ University of Goettingen, Goettingen, Germany \\ b Tomsk State University, Tomsk, Russia \\ ${ }^{\mathrm{c}}$ Mediterranean Institute of Marine and Terrestrial Biodiversity and Ecology, Aix-en-Provence, France \\ d University of Illinois, Urbana-Champaign, USA \\ e Lower Saxony Institute for Historical Coastal Research, Wilhelmshaven, Germany
}

Keywords:

Palaeomycology

Xylomyces

Dictyosporium

Sporoschisma

Freshwater fungi

Lignicolous fungi

Fossil fungi

\begin{abstract}
A B S T R A C T
The first Holocene record of the freshwater ascomycete Megalohypha aqua-dulces from the sediment core Kongor (NE Iran) is presented here. Based on the similarity of the spore morphology with the fossil form genus Fusiformisporites, we establish a link between extant and fossil taxa. Comparative analysis of morphological characteristics of fossil spores of Fusiformisporites indicates that several different fungal groups might be included in this form genus. At least five species of Fusiformisporites share similar morphology with spores of Megalohypha aqua-dulces: Fusiformisporites annafrancescae, Fusiformisporites crabbii, Fusiformisporites keralensis, Fusiformisporites paucistriatus, and Fusiformisporites pseudocrabbii. Based on Fusiformisporites, the evolution of Megalohypha aqua-dulces can be traced to the late Cretaceous, corresponding with diversification of the flowering plants and pointing to a co-evolution of both groups. Megalohypha aqua-dulces has a tropical to subtropical distribution but also occurs in the semi-arid steppe environments of Kongor together with other freshwater fungal genera such as Xylomyces, Dictyosporium, and Sporoschisma, which spores we describe here. The ecological requirements of Megalohypha indicate that its spores can be used for the palaeoecological sign of dead submerged wood as well as of tropical to subtropical conditions.
\end{abstract}

\section{Contents}

1. Introduction . . . . . . . . . . . . . . . . . . . . . . . . . . . . . . . . . . . . . . . . . . . . . . . . . . . . 168

2. Material and methods. . . . . . . . . . . . . . . . . . . . . . . . . . . . . . . . . . . . . . 169

3. Results . . . . . . . . . . . . . . . . . . . . . . . . . . . . . . . . . . . . . . 169

3.1. Spore morphology of Megalohypha aqua-dulces . . . . . . . . . . . . . . . . . . . . . . . . . . . . . . . . 169

3.2. Records of freshwater fungi in Kongor . . . . . . . . . . . . . . . . . . . . . . . . . . . . . . . . . . . . . . . . . . 169

4. Discussion ... . . . . . . . . . . . . . . . . . . . . . . . . . . . . . . . . 173

4.1. Taxonomic relationship between Fusiformisporites and Megalohypha aqua-dulces . . . . . . . . . . . . . . . . . . . . . . . . . . 173

4.2. Ecology and palaeoecology . . . . . . . . . . . . . . . . . . . . . . . . . . . . . . . . . . . . . . . . 173

4.3. Geological evidence for the evolution of aquatic ascomycetes. . . . . . . . . . . . . . . . . . . . . . . . . . . . . . . . . . 174

5. Conclusions . . . . . . . . . . . . . . . . . . . . . . . . . . . . . . . . . . . . . . . . . . . . . . . 175

Acknowledgements . . . . . . . . . . . . . . . . . . . . . . . . . . . . . . . . . . . . . . . . . 175

References . . . . . . . . . . . . . . . . . . . . . . . . . . . . . . . . . . . . . . . . . . . . . . . . . . . . 175

\footnotetext{
* Corresponding author at: University of Goettingen, Albrecht-von-Haller-Institute for Plant Sciences, Department of Palynology and Climate Dynamics, Wilhelm-Weber-Str. 2a, 37073 Goettingen, Germany.

E-mail address: lshumil@gwdg.de (L.S. Shumilovskikh).
} 


\section{Introduction}

Morphologically distinctive fungal spores present in the geological record provide valuable information about a wide variety of environmental conditions, including climate, hydrological conditions, fire and erosion history, vegetation type, and organismal interactions (e.g. Elsik, 1976; Sherwood-Pike, 1988; Pirozynski, 1989; Van Geel and Aptroot, 2006; Taylor et al., 2015). The description of fossil fungal spores is usually carried out based on fossil material, which rarely provides identification to extant taxa (Elsik, 1976; Jansonius and Kalgutkar, 2000). Studies on the relationship between extant and fossil taxa however deliver important information for geological and mycological research by combining geological records with known fungal ecology. For example, investigation of the monotypic genus Potamomyces indicate that it likely contains several species (Schlütz and Shumilovskikh, 2013; Nuñez Otaño et al., 2016), or in the case of Caryospora callicarpa led to the discovery of species thought to be extinct (Hawksworth et al., 2016). Further connections of fossil fungal spores to recent species are required for a deeper understanding of the history, evolution, ecology and (palaeo)geography of fungal taxa.

During palynological investigations of a sediment core from Kongor (NE Iran), covering the last 6000 years (Shumilovskikh et al., 2016), fungal spores of Megalohypha aqua-dulces Ferrer et Shearer were documented (Plate I) and identified using mycological literature (Ferrer et al., 2007). These spores share similar characteristics to additional fossilised spores from geological records described as Fusiformisporites Rouse, 1962. Continuing our series of "non-pollen palynomorphs notes" (Schlütz and Shumilovskikh, 2017), in this paper we provide the first Holocene record of the extant species Megalohypha aqua-dulces and discuss its relation to the fossil form genus Fusiformisporites.

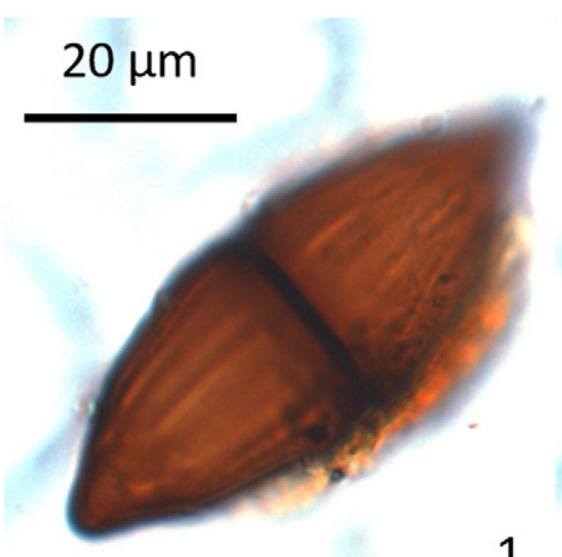

1
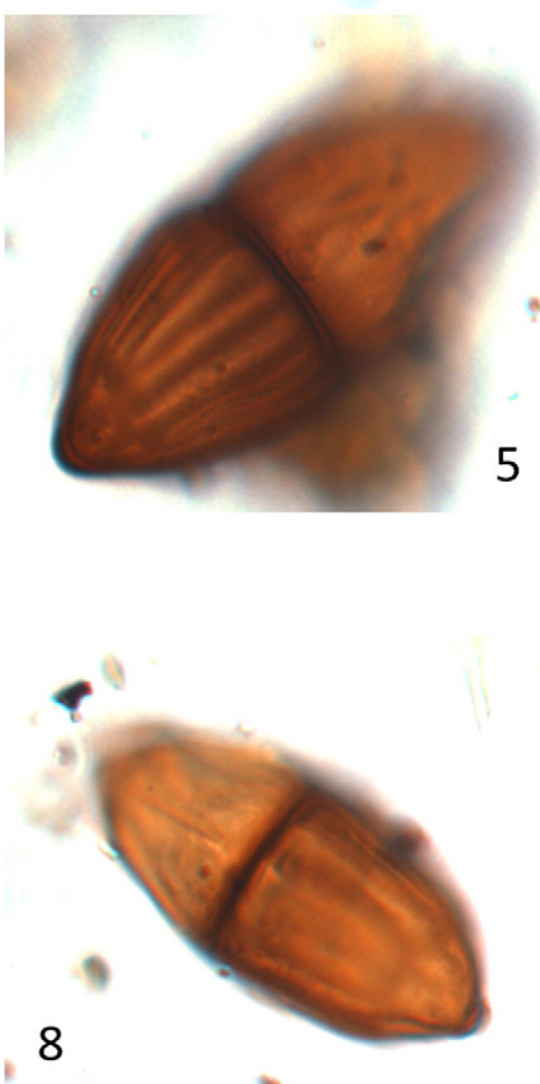

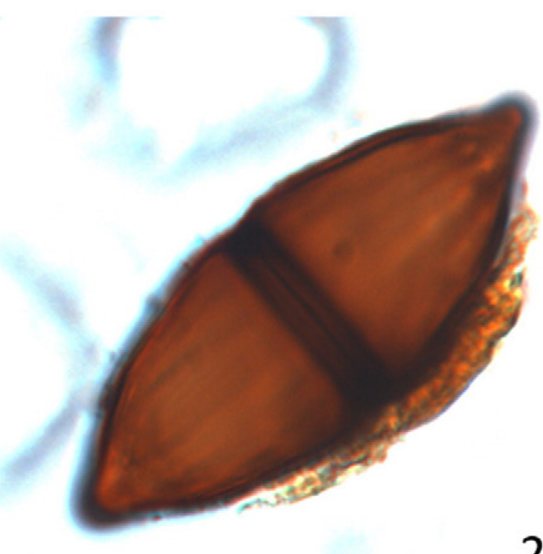

2

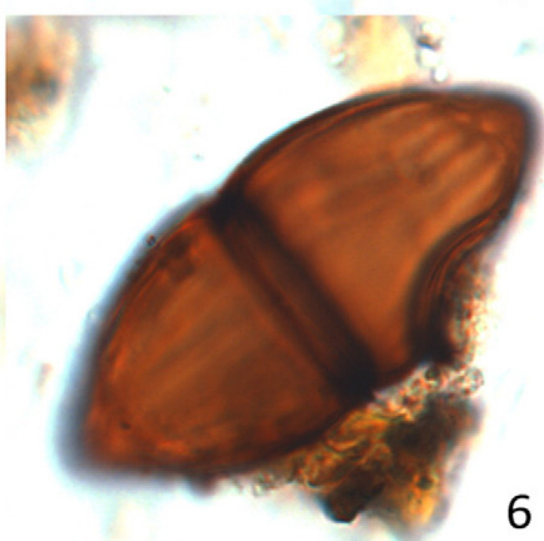

6

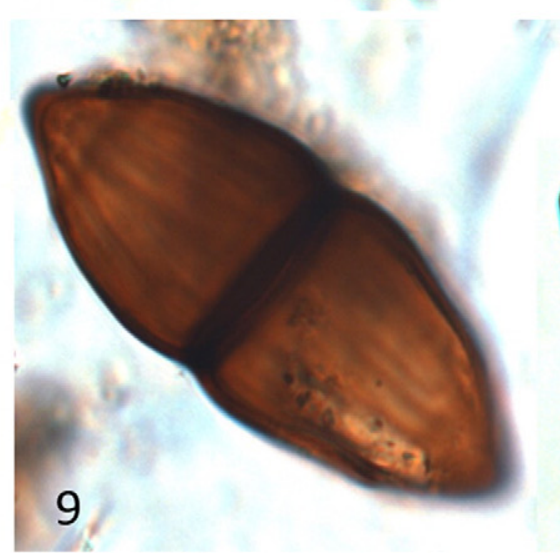

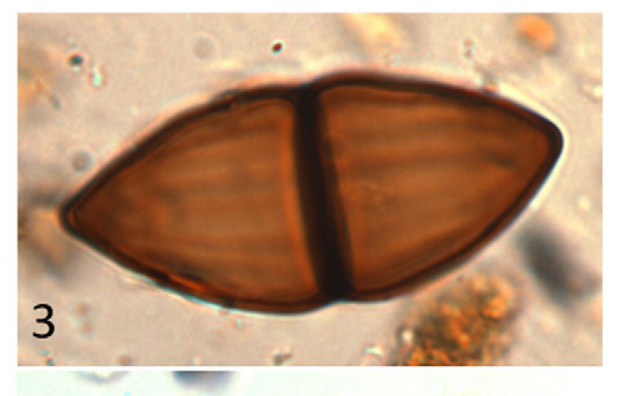

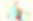
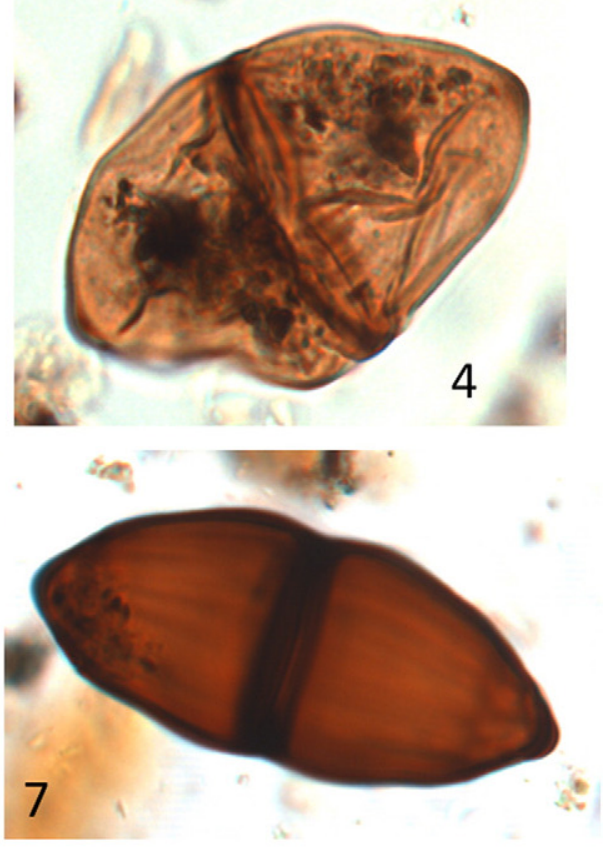

10

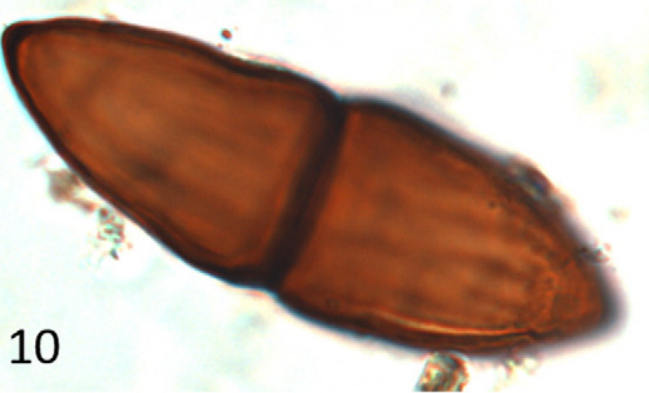

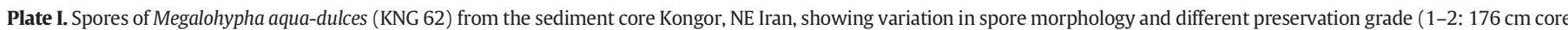
depth, 3: $224 \mathrm{~cm}, 4: 64 \mathrm{~cm}, 5-6: 48 \mathrm{~cm}, 7-8: 96 \mathrm{~cm}, 9: 72 \mathrm{~cm}, 10: 80 \mathrm{~cm}$ ). Photos at 500× magnification with oil immersion. 


\section{Material and methods}

The Kongor core was obtained from the temporary lake Kongor, located in the Artemisia-steppe of the eastern Gorgan Plain, NE Iran. Samples from the core were treated with standard palynological laboratory procedures and studied for pollen and non-pollen palynomorphs including microscopic plant, animal and fungal remains (details in Shumilovskikh et al., 2016). For the purpose of this paper we present an abbreviated version of the palynological diagram with freshwater fungi, arboreal pollen and tree and shrub macroremains (Fig. 1). The description of the Megalohypha aqua-dulces spores (Plate I) and of the spores of other freshwater fungi (Plate III) from the sediment core Kongor follows the scheme of Elsik (1983) with an abbreviation KNG (Kongor) for the first described types. Spore measurements were carried out on $1000 \times$ magnification.

The samples from Panama were collected from freshwater habitats at the Soberania National Park, which support lowland tropical forest. Samples of submerged partially decomposed wood were incubated in the laboratory in plastic boxes containing moistened paper towels at room temperature and examined with a dissecting microscope periodically over 12 months. Fungi were removed from the substrate and placed in a drop of distilled water on a glass slide. Measurements and photographs of the spores and fruiting bodies were made in material mounted in distilled water (Plate II; Ferrer et al., 2007).

\section{Results}

\subsection{Spore morphology of Megalohypha aqua-dulces}

Spores of Megalohypha aqua-dulces from the sediment core Kongor (KNG 62; Plate I): spores are fusiform, dark reddish-brown, dicellate, $47-60 \times 21-27 \mu \mathrm{m}$ (average $=54.4 \times 23.4 \mu \mathrm{m}, \mathrm{SD}=4.5 \times 1.7 \mu \mathrm{m}$, $\mathrm{n}=10$ ), inaperturate, slightly constricted at the septum, wall

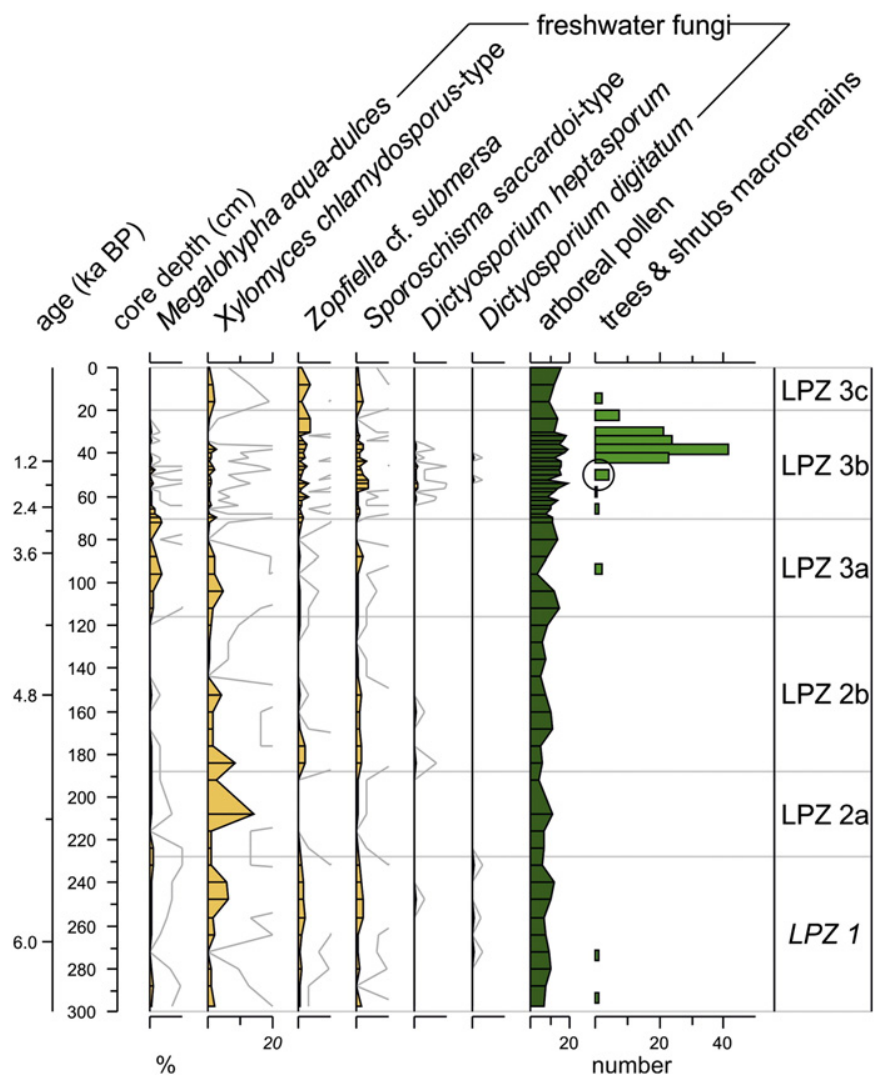

Fig. 1. Freshwater fungi in the palynological record of the Kongor sediment core. Grey lines show exaggeration line $\times 10$. Circle indicates presence of Morus alba wood. thickness $1-1.5 \mu \mathrm{m}$, up to $3 \mu \mathrm{m}$ at apices. The axis is straight, 2 symmetrical cells are separated by a septum $2-3 \mu \mathrm{m}$ thick. The sculpture is longitudinally striate with 5-7 ridges exposed on each flattened sector. The striate pattern merges to a coarse reticulum at the apices.

The morphology corresponds to the original description of spores of the extant fungus Megalohypha aqua-dulces (Ferrer et al., 2007): ascospores $40-55 \times 19-22 \mu \mathrm{m}$ (mean $=48.3 \times 18.8 \mu \mathrm{m}, \mathrm{SD}=2.8 \times 0.91$ $\mu \mathrm{m}, \mathrm{n}=30$ ), ellipsoidal, acutely tapered at apices, brown to dark brown, 1-septate, septum appearing as a dark band, both cells of equal shape and size, rough walled with longitudinal sulcate striations lacking appendages or a gelatinous sheath (Plate II).

In addition, the spores from Kongor resemble spores of the fossil form genus Fusiformisporites Rouse, 1962 with holotype Fusiformisporites crabbii Rouse, 1962 (Kalgutkar and Jansonius, 2000): spores are distinctly fusiform in outline. The unit is split into two equal halves by an equatorial wall that appears to be continuous, thus completely dividing the unit. Longitudinal grooves spread out along the wall from either pole like a spindle; some reach the equator, others stop short of it. Only occasionally is a groove continuous across the dividing wall. The wall is moderately thick, about $3 \mu \mathrm{m}$. Ornamentation levigate. Size range $20-100 \mu \mathrm{m}$. Size of Fusiformisporites crabbii is 45$52 \mu \mathrm{m}$ (Rouse, 1962).

According to Kalgutkar and Jansonius (2000), Fusiformisporites includes forms with less obvious parallel ornamentation elements (striations) (Table 1). The authors place it taxonomically into Fungi Imperfecti, Didimosporae.

\subsection{Records of freshwater fungi in Kongor}

In the Kongor sediment core, Megalohypha aqua-dulces occurs together with freshwater lignicolous fungi such as Sporoschisma saccardoi-type, Dictyosporium heptasporum, Dictyosporium digitatum, Zopfiella cf. submersa, and Xylomyces chlamydosporus-type (Fig. 1). Arboreal pollen varies between 5 and 20\% throughout the record. Macroremains of trees and shrubs, including seeds, epidermis and wood, occur in the upper metre of the core.

Below we provide a description of the spores of freshwater fungi from the Kongor site.

Dictyosporium digitatum (KNG 27b; Plate III: 4-6)

Conidia are 58-62 $\times 28-32 \mu \mathrm{m}$ in size, reddish-brown, multiseptate, composed of 6-7 parallel arms, closely branched from the terminal cell, flattened in one plane. The wall is smooth, about $1 \mu \mathrm{m}$ thick. The spore morphology resembles Dictyosporium digitatum Chen, Hwang, Tzean, which is commonly found on submerged dead wood in Australia, Brunei Darussalam, Hong Kong, Seychelles, Taiwan, and Thailand (Goh et al., 1999). In Kongor, five spores were found from the Middle and Late Holocene (Fig. 1; Shumilovskikh et al., 2016).

Dictyosporium heptasporum (HdV 1053 by Van Geel et al., 2011; Plate III: $1-3$ )

Conidia are $62-68 \times 22-26 \mu \mathrm{m}$ in size, with 7 parallel arms, branched from the terminal cell in form of a cylinder, apices of arms are incurved. The spore morphology resembles Dictyosporium heptasporum with conidia broad ellipsoidal, 42-71 $\times 21-25 \mu \mathrm{m}$, branched, composed of ca. 7 rows of cells (Damon, 1952). Van Geel et al. (2011) described type HdV 1053 from Lake Challa in Africa and identified them as Dictyosporium cf. heptasporum (Garov.) Damon. Two species of Dictyosporium have similar size and cylindrical morphology of conidia: D. heptasporum and Dictyosporium cocophilum (Goh et al., 1999). However, the apex of the arms is straight by the latter species. Therefore, we identified our specimen as D. heptasporum. Dictyosporium heptasporum has been observed on dead wood and submerged wood in Australia, Belize, Brunei Darussalam, Cuba, Europe, Hong Kong, India, Ecuador, Mexico, Peru, Taiwan, Tanzania, Thailand, USA (Goh et al., 1999). Subfossil finds are known from the Late Holocene from Lake Challa (Africa, Van Geel et al., 2011) and the Middle and Late Holocene from Kongor (NE Iran, Shumilovskikh et al., 2016). Spores of another 

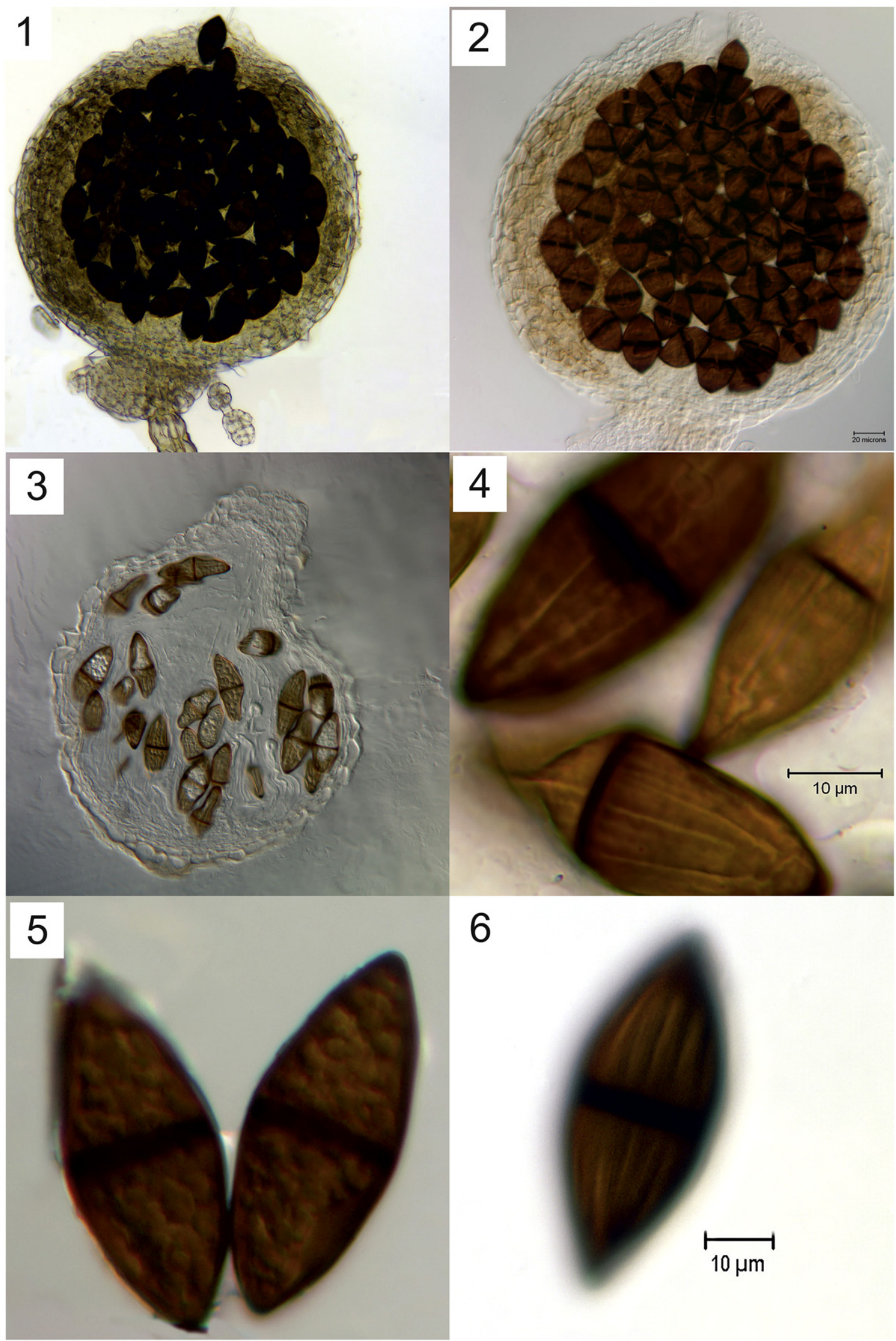

6

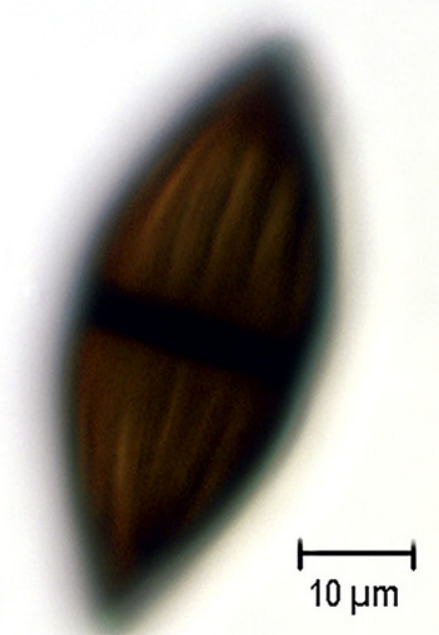

Plate II. Megalohypha aqua-dulces (1-2) grown in culture (Holotype AF005-2) and (3-6) collected from wood (Holotype AF005-1): 1-2: stalked ascomata, 3: longitudinal section through ascoma, 4: surface of ascospores with coarse reticulum at apices, 5: longitude section through ascospores, 6: surface of ascospores with sulcate striations. Further details in Ferrer et al. (2007). 
Table 1

Morphological characteristics of Megalohypha aqua-dulces and Fusiformisporites species (based on Kalgutkar and Jansonius, 2000; Ferrer et al. 2007).

\begin{tabular}{|c|c|c|c|c|c|c|c|}
\hline Species & $\begin{array}{l}\text { Length } \\
(\mu \mathrm{m})\end{array}$ & $\begin{array}{l}\text { Width } \\
(\mu \mathrm{m})\end{array}$ & Wall & Septum & Striation & Apical ends & Form \\
\hline $\begin{array}{l}\text { Megalohypha aqua-dulces } \\
\text { Ferrer \& Shearer } 2007\end{array}$ & $40-55$ & $19-22$ & - & Dark band & Sulcate striations & Acutely tapered & Fusiform \\
\hline $\begin{array}{l}\text { Subfossil M. aqua-dulces } \\
\text { (present study) }\end{array}$ & $47-60$ & $21-27$ & $1-1.5 \mu \mathrm{m}$ & $2-3 \mu \mathrm{m}$ & 5-7 grooves with broader ridges & Facetted sectors & Fusiform \\
\hline $\begin{array}{l}\text { Fusiformisporites } \\
\text { annafrancescae Norris } \\
1997\end{array}$ & $44-55$ & $19-24$ & $\begin{array}{l}0.25-0.5 \mu \mathrm{m}(1 \mu \mathrm{m} \\
\text { at apices })\end{array}$ & $1-2 \mu \mathrm{m}$ & $0.25-0.5 \mu \mathrm{m}$ wide, spaced $0.5-1 \mu \mathrm{m}$ & Facetted sectors & Fusiform \\
\hline F. crabbii Rouse 1962 & $45-52$ & - & & $3 \mu \mathrm{m}$ & $\begin{array}{l}5 \text { grooves exposed on each flattened } \\
\text { sector }\end{array}$ & - & Fusiform \\
\hline $\begin{array}{l}\text { F. duenasii Kalgutkar } \\
\text { and Jansonius } 2000\end{array}$ & $28-32$ & $8-10$ & - & - & - & - & - \\
\hline $\begin{array}{l}\text { F. elongatus Ramanujam } \\
\text { \& Rao } 1978\end{array}$ & $35-38.5$ & $8-12$ & $1 \mu \mathrm{m}$ & $2.5 \mu \mathrm{m}$ & Fine striate with ridges as thick as grooves & Blunt ends & - \\
\hline $\begin{array}{l}\text { F. foedus Salujha, Kindra } \\
\text { \& Rehman } 1974\end{array}$ & $43.2-46.4$ & $24.5-27.2$ & $1.2 \mu \mathrm{m}$ & $2-2.5 \mu \mathrm{m}$ & 10 ridges about $1.5 \mu \mathrm{m}$ wide & Pointed ends & - \\
\hline $\begin{array}{l}\text { F. keralensis Ramanujam } \\
\text { \& Rao } 1978\end{array}$ & $51-56$ & $32-36$ & $\begin{array}{l}1.5 \mu \mathrm{m}, \text { much } \\
\text { thicker at each end }\end{array}$ & $4 \mu \mathrm{m}$ & $\begin{array}{l}\text { Striae numerous, ridges slightly broader } \\
\text { than grooves }\end{array}$ & $\begin{array}{l}\text { Ends truncate to broadly } \\
\text { arched }\end{array}$ & $\begin{array}{l}\text { Fusiform to } \\
\text { rhomboidal }\end{array}$ \\
\hline $\begin{array}{l}\text { F. lineatus Rouse \& } \\
\quad \text { Mustard } 1997\end{array}$ & $58-62$ & $23-29$ & $\begin{array}{l}0.75-1.0 \mu \mathrm{m} \\
\text { uniform }\end{array}$ & - & $\begin{array}{l}3-5 \text { in each cell with a uniform width of } \\
0.3-0.9 \mu \mathrm{m}\end{array}$ & $\begin{array}{l}\text { Polar cap readily detaches or } \\
\text { hinges open }\end{array}$ & Fusiform \\
\hline $\begin{array}{l}\text { F. lineolatus Sheffy and } \\
\text { Dilcher } 1971\end{array}$ & 33.8 & 18.4 & - & $1 \mu \mathrm{m}$ & $6-7$ ribs & - & Fusiform \\
\hline $\begin{array}{l}\text { F. mackenziei Parsons \& } \\
\quad \text { Norris } 1999\end{array}$ & $31-41$ & $15.5-24$ & Thicker at apices & $\begin{array}{l}\text { Incompl. } \\
\text { septate }\end{array}$ & 15 to 20 ribs & $\begin{array}{l}\text { Rounded apices, slight apical } \\
\text { nub }\end{array}$ & Fusiform \\
\hline F. marii Elsik 1968 & 21 & 12 & $1 \mu \mathrm{m}$ & $\begin{array}{l}\text { Thicker than } \\
\text { wall }\end{array}$ & $\begin{array}{l}\text { Two ridges in one hemisphere rotated } 90^{\circ} \\
\text { from two ridges in the opposite } \\
\text { hemisphere }\end{array}$ & - & $\begin{array}{l}\text { Capsular to } \\
\text { ovoid }\end{array}$ \\
\hline $\begin{array}{l}\text { F. microstriatus Hopkins } \\
1969\end{array}$ & $42-49$ & - & Thick, granular & - & Fine longitudinal ribs & - & Oval \\
\hline $\begin{array}{l}\text { F. paucistriatus Rouse \& } \\
\text { Mustard } 1997\end{array}$ & $39-42$ & $15-22$ & $0.25-0.5 \mu \mathrm{m}$ & - & 3-10 striae, very thin, irregular & $1.5-2 \mu \mathrm{m}$ thick at apices & - \\
\hline $\begin{array}{l}\text { F. pseudocrabbii Elsik } \\
1968\end{array}$ & $40-45$ & 25 & $\begin{array}{l}\text { Inner layer } 0.5 \mu \mathrm{m} \text {, } \\
\text { outer } 0.5-1.5 \mu \mathrm{m}\end{array}$ & $\begin{array}{l}2 \mu \mathrm{m} ; \text { two } \\
\text { layers }\end{array}$ & Broad longitudinal ribs or folds & $1.5-2 \mu \mathrm{m}$ thick at apices & Fusiform \\
\hline $\begin{array}{l}\text { F. rugosus Sheffy and } \\
\text { Dilcher } 1971\end{array}$ & 43.5 & 19.3 & - & $2-3 \mu \mathrm{m}$ & Folds and tears, $1 \mu \mathrm{m}$ thick & $\begin{array}{l}\text { Rounded at one apex, with } \\
\text { flat basal attachment at other } \\
\text { end }\end{array}$ & Fusiform \\
\hline $\begin{array}{l}\text { F. striatus (Ke \& Shi) } \\
\quad \text { Kalgutkar and } \\
\text { Jansonius } 2000\end{array}$ & 46.4 & 29 & $\begin{array}{l}1.5 \mu \mathrm{m} \\
\text { two-layered, outer } \\
\text { layer thicker }\end{array}$ & $\begin{array}{l}3 \mu \mathrm{m} \text { divided } \\
\text { into two } \\
\text { layers }\end{array}$ & Six sulci & - & Elliptical \\
\hline
\end{tabular}

species, Dictyosporium australiense, have been documented from Holocene peat sediments from Germany (Shumilovskikh et al., 2015).

Sporoschisma saccardoi-type (UG 1002 by Gelorini et al., 2011; Plate III: 13-15)

Conidia are 45-50 $\times 15-17 \mu \mathrm{m}$ in size, composed of 4 to 6 cells with dark central and hyaline short apical cells, subtruncate at both ends; the spore is slightly constricted at septa, with a smooth wall 1-2 $\mu \mathrm{m}$ thick. Inner dark septa 3-4 $\mu \mathrm{m}$ thick, distal septa 1-1.5 $\mu \mathrm{m}$. Central cells are normally equal but sometimes unequal (compare Plate III: 13 and 14). Some spores were found within the conidiophore, showing production of 5 and 3-septate spores by the same fungus specimen (Plate III: 15). Gelorini et al. (2011) associated the type UG 1002 with Sporoschisma spp. possibly with Sporoschisma saccardoi. In addition, at least Sporoschisma nigroseptatum has similar morphology (Goh et al., 1997b) and may be another Sporoschisma species, therefore here the Sporoschisma saccardoi-type is erected. Both species have been observed on submerged dead wood from Australia, Brunei Darussalam, Ecuador, Europe, Hong Kong, Indonesia, Malaysia, Peru, South Africa, Taiwan (Goh et al., 1997b). Subfossil spore finds are known from African modern lake sediments (Gelorini et al., 2011), Holocene sediments from NE Iran (Shumilovskikh et al., 2016) and terrestrial surface samples from Nepal (Shumilovskikh, unpubl.). Prager et al. (2006) affiliated EMA 12 to Sporoschisma or Chalara or hyphae. Morphologically EMA 12 differs from conidia of Sporoschisma saccardoi-type, and it might be a part of hyphae.

Xylomyces chlamydosporus-type (KNG 7; Plate III: 16-17)

Conidia are $145-255 \times 35-40 \mu \mathrm{m}$ in size, fusiform, straight or slightly curved, dark-brown with pale end cells. Spores have 6-14 septa, 2-5 $\mu \mathrm{m}$ thick. Spores are constricted at septa. The wall is $2-4 \mu \mathrm{m}$ thick with scarce irregular longitudinal ornamentation (rugulate to coarse striate). Based on similar morphology, the type KNG 7 is assigned to hyphomycete genus Xylomyces. According to mycobank database (www. mycobank.org), the genus Xylomyces consists of nine species but only four, Xylomyces chlamydosporus Goos, Brooks \& Lamore, Xylomyces giganteus Goh, Ho, Hyde \& Tsui, Xylomyces rhizophorae Kohlm. \& Volkm.-Kohlm. and Xylomyces acerosisporus Oliveira, Malosso \& Castañeda, produce large spores over $140 \mu \mathrm{m}$ long with 6-14, 6-26, 11-43(-64) and 7-15 septa, respectively (Goos et al., 1977; Goh et al., 1997a; Kohlmeyer and Volkmann-Kohlmeyer, 1998; Oliveira et al., 2015). Morphologically, the type KNG 7 is the most close to $X$. chlamydosporus and X. giganteus. For this two and possibly upcoming species with same spore morphology the $X$. chlamydosporus-type is erected here.

Xylomyces chlamydosporus is the type species of Xylomyces and it was first described from dead, decaying wood submerged in freshwater in southern Rhode Island and Alabama (Goos et al., 1977). The fungus was found during all seasons at water temperature ranging from 1.7 to $23.8^{\circ} \mathrm{C}$; it grows well on laboratory media within temperature range 15 to $30{ }^{\circ} \mathrm{C}$ and at salinities of up to $22.15 \%$ (Goos et al., 1977). Its known distribution is from Brunei Darussalam, Hong Kong, Seychelles, and the United States (Goh et al., 1997a). Xylomyces giganteus was described from submerged wood in Australia and is also found in South Africa and United Kingdom (Goh et al., 1997a). Our findings reveal the presence of $X$. chlamydosporus-type during the Late Holocene in NE Iran. Campbell et al. (2007) refer Xylomyces to the order Jahnulales based on the wide mycelium and molecular evidence, while Sivichai et 

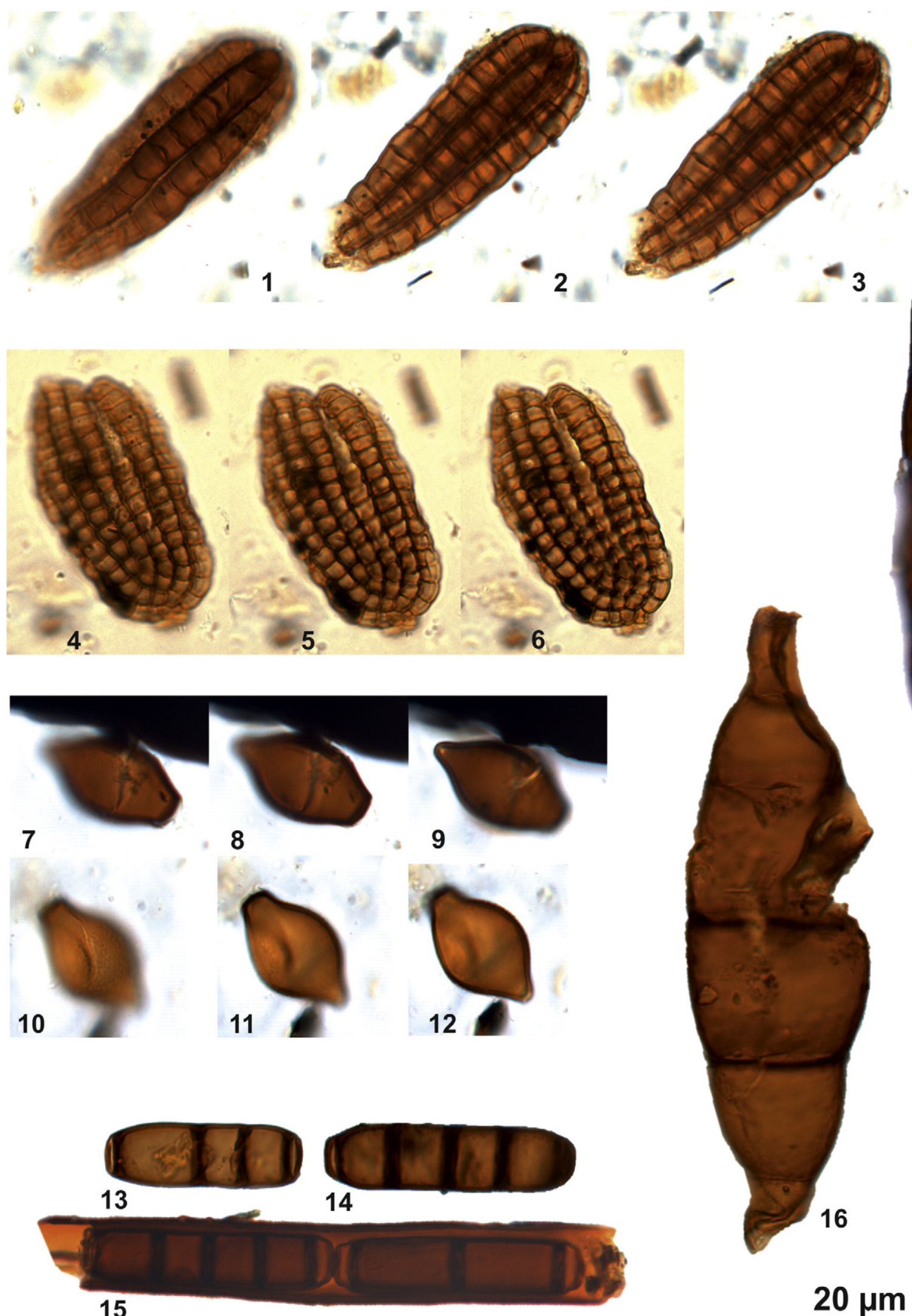
al. (2011) made a connection between X. chlamydosporus (anamorph) and Jahnula aquatica (teleomorph).

Goos et al. (1977) assigned Xylomyces chlamydosporus to the fossil fungus Pluricellaesporites psilatus Clarke known from late Cretaceous (Clarke, 1965). Recently, spores of Xylomyces giganteus are reported from the early Eocene formation Princeton Chert (Klymiuk et al., 2013).

Zopfiella cf. submersa (KNG 60; Plate III: 7-12)

Spores are $28-30 \times 18-20 \mu \mathrm{m}$ in size, limoniform, truncate at the base, dark-brown, with a subapical germ pore of $0.5-1 \mu \mathrm{m}$ diameter, umbonate at the apex. The wall is $2-3 \mu \mathrm{m}$ thick with a coarse scabrate surface. The spores resemble Zopfiella submersa Guarro, Al-Saadon, Gené et Abdullah, however its upper melanized cell is smaller (13.0$20.5 \times 10-14 \mu \mathrm{m})$. It is possible to assume a change of the spore size due to fossilisation processes or laboratory preparations or appearance of other Zopfiella species. For example, Zopfiella inermis has the largest spores in the genus $(28-32 \times 18-21 \mu \mathrm{m})$ (Malloch and Cain, 1971), corresponding well to the size of KNG 60. Unfortunately, we could not access the original publication for comparison of all morphological characteristics. Therefore, KNG 60 is named Zopfiella cf. submersa. Although different Zopfiella species grow on a wide range of substrates such as herbaceous debris, rotten wood, dung, and soil in terrestrial and marine environments, Z. submersa was first described from the Euphrates River in Iran, on submerged dead culms of Phragmites and Arundo donax (Guarro et al., 1997).

\section{Discussion}

\subsection{Taxonomic relationship between Fusiformisporites and Megalohypha aqua-dulces}

Fusiformisporites has a long identification history. The fossil form genus Fusiformisporites was first described by Rouse (1962) from the Tertiary sediments of the Burrard Formation of western British Columbia. In describing the genus Fusiformisporites and F. crabbii as the holotype, Rouse (1962) suggested a relationship to algae such as Desmatractum bipyramidatum (Chodat) Pascher or oospores of Oedogonium, both are representatives of the Chlorococcaceae, or representatives of the Class Desmocontae (Division Pyrrophyta). However, this view was not supported.

Later Elsik (1968) recognised the fungal nature of Fusiformisporites and affiliated the genus to the extant fungus Cookeina, as illustrated by Wolf (1967). Indeed, describing fungal spores from East African lake sediments, Wolf (1967) drew a 2-celled fungal spore with striation and erroneously named it Cookeina, a wood inhabiting pantropical genus from the Pezizales. In fact, ascospores of Cookeina can bear striations but consist of only one-cell (Iturriaga and Pfister, 2006; Weinstein et al., 2002), contradicting Wolf's (1967) drawings and the morphology of Fusiformisporites spores. Nevertheless, Fusiformisporites affinity to Cookeina was used in further geological studies (Germeraad, 1979; Kalgutkar and Jansonius, 2000; Singh and Chauhan, 2008; Massini and Jacobs, 2011; Taylor et al., 2015). While referring to a personal communication of Elsik in 1996, Rull and Vegas-Villarúbia (1999) suggested that Fusiformisporites might be a dung fungus, indicating foraging and grazing animals. However, they did not affiliate it to any species. Carrión and van Geel (1999) and Carrión and Navarro (2002) note an absence of published connections to extant fungal taxa and suggest a possible affinity of Fusiformisporites to ascospores of Nectria peziza, Herpotrichia lignicola, Parodiella perisporioides or Ceriophora palustris. However, all these species have different spore morphology.

Studying Holocene sediments from salt marshes, Marsh and Cohen (2008) suggested correspondence of Fusiformisporites duenasii to Atrotorquata lineata (Cainiaceae, Xylariales), which was described from standing culms of Juncus roemerianus. Similar spore morphology of both species supports this connection.

The morphology of spores from the Kongor sediment core is comparable to the morphology of Megalohypha aqua-dulces. The larger size of the spores from the Kongor core (Table 1) can be explained by fossilisation processes or laboratory treatment or storing in glycerine. Influence of these processes on size is well-known for pollen, but similar studies have not been done for fungal spores. The spores share similar characteristics to some species of the fossil form genus Fusiformisporites. From 15 described fossil species of Fusiformisporites (Table 1), seven species have a similar size as Megalohypha aqua-dulces: Fusiformisporites annafrancescae, Fusiformisporites crabbii, Fusiformisporites keralensis, Fusiformisporites paucistriatus, Fusiformisporites pseudocrabbii, Fusiformisporites rugosus, and Fusiformisporites striatus. Apical thickness is described and seen on the drawings of four species: F. crabbii, F. keralensis, F. paucistriatus, and F. pseudocrabbii. Only F. annafrancescae has distinct facetted sectors in the description. The spore diversity of Megalohypha aqua-dulces from the Kongor core shows that facetted sectors are not easy to see in decomposed spores (Plate I: 4). Combining all morphological features, we suggest that $F$. crabbii, F. keralensis, $F$. paucistriatus, $F$. pseudocrabbii and $F$. annafrancescae can all be affiliated to Megalohypha aqua-dulces. Most likely other representatives of Fusiformisporites belong to different fungal taxa.

\subsection{Ecology and palaeoecology}

The fungus Megalohypha aqua-dulces A. Ferrer et Shearer is described from submerged wood in tropical forest streams in Panama and Thailand (Ferrer et al., 2007). Studies on 18 S and 28 S nuclear ribosomal DNA sequences supported its position in the order Jahnulales (Campbell et al., 2007). Molecular phylogeny places Megalohypha aqua-dulces within the Jahnula sensu stricto clade in the polyphyletic genus Jahnula (Suetrong et al., 2011). Similar to other freshwater ascomycetes, Megalohypha aqua-dulces is an important degrader of wood in fresh water, playing a key role in the process of carbon mineralization. It produces a wide spectrum of enzymes such as general cellulases, endoglucanase, $\beta$-glucosidase, xylanase, laccase, amylase, pectic lyase, and polygalacturonase, making the degradation of cellobiose, hemicellulose, lignin, starch and pectin possible (Simonis et al., 2008). Ferrer et al. (2007) suggested that the occurrence of soft rot cavities was caused by Megalohypha aqua-dulces, however further experimental studies did not support this conclusion (Simonis et al., 2008).

In general, freshwater ascomycetes grow in freshwater habitats and complete part or the whole of their lifecycle in water (Cai et al., 2006). They can be recorded in terrestrial and marine habitats and therefore are divided in four major groups according to their occurrence: 1) exclusively freshwater; 2) freshwater and terrestrial; 3) freshwater and marine; 4) freshwater, marine and terrestrial (Vijaykrishna et al., 2006). Since Megalohypha aqua-dulces was described from freshwater habitats, and the known Holocene occurrences are from freshwater environments, the species likely belongs to the first group. However, spores of $F$. pseudocrabbii were described from the Tertiary coastal to marginal marine environment in the Eastern Niger Delta in Nigeria (Ajaegwu et al., 2012), possibly suggesting the ability of Megalohypha aqua-dulces to occupy marine habitats.

While the entire group of freshwater fungi was highlighted for its importance in the palaeoecological studies (Sherwood-Pike, 1988), Megalohypha aqua-dulces has a potential to be used as palaeoecological indicator for presence of wood. In the Kongor sediment core, Megalohypha aqua-dulces represents a part of the freshwater fungal spore assemblage (Fig. 1). Being described from submerged wood, Megalohypha aqua-dulces indicates presence of decaying wood and therefore trees or shrubs growing on, or near the sampling site. This interpretation is supported by the presence of other wood decomposers such as conidia of Xylomyces chlamydosporus-type, Dictyosporium digitatum and Dictyosporium heptasporum (Cai et al., 2006). In addition, Zopfiella cf. submersa grows on herbaceous debris or wood while Sporoschisma saccardoi-type is saprobic on decaying wood and bamboo culms (Cai et al., 2006). Interestingly, the continuous presence of woody vegetation on the Kongor site is neither indicated by pollen nor by 
macroremains (Fig. 1), but by insects, strongly suggesting the presence of riverine forests with Alnus or Salix close to the site (Shumilovskikh et al., 2016). In fact, pollen of woody vegetation is present in the pollen diagram (4-20\%), but due to possible long-distance transport it is not possible to infer local vegetation (Fig. 1). Macroremains of trees and shrubs provide a very local signal but can rapidly become decomposed. Remains of Rubus, Sambucus, Morus, and Viscum occur in the upper $60 \mathrm{~cm}$ of the core, but are almost completely absent in the lower part (Fig. 1), possibly due to decomposition. Considering the biology of Megalohypha aqua-dulces, it is possible that wood of the abovementioned trees and shrubs as well as of shrubby Artemisia or Chenopodiaceae might be the possible substrates for the development of freshwater lignicolous fungi at the Kongor site.

The presence of spores of freshwater fungi in sediments provides opportunities to infer the presence of woody vegetation development at a site. This can be used, for example, for testing of the gallery forest theory in South America. Our preliminary results on the sediment core São Francisco de Assis from southern Brazil (Behling et al., 2005) provides evidence for the first occurrence of Megalohypha aqua-dulces in association with Potamomyces spp. (Schlütz and Shumilovskikh, 2013; Nuñez Otaño et al., 2016) in the mid-Holocene while it is absent from the sediment during the late glacial and early Holocene. In contrast, a core from Aguas Claras near Porte Alegre (SE Brasil) shows the presence of Megalohypha aqua-dulces during the late glacial (Medeanic and Silva, 2010).

Freshwater ascomycetes have pan-tropical or pan-temperate distributions and may overlap in warm temperate or subtropical regions. The optimum temperature for tropical and temperate freshwater ascomycetes is $20-25^{\circ} \mathrm{C}$ (Vijaykrishna et al., 2006). Recent documentation of Megalohypha aqua-dulces spores in Holocene peat cores from Indonesia (Fig. 2) confirms its pantropical distribution. Occurrence of the fungus in the peatland of Northern Iran and southern Brazil expands the known distribution of Megalohypha aqua-dulces to more arid subtropics, highlighting its ecological plasticity.

The modern distribution of Megalohypha aqua-dulces in the tropics, and its Holocene occurrence in the subtropics suggest that it is a good indicator of warm humid conditions in the Tertiary, as proposed from geological records for Fusiformisporites (Elsik, 1968; Kumar, 1990; Oboh, 1992; Kalgutkar, 1997). Carrión and van Geel (1999) and Carrión and Navarro (2002) use Fusiformisporites sp. as indicators of organic matter decomposition and peaty layer formation in deposits of the Canal de Navarrés (Spain), whereas the presence of Megalohypha aquadulces provides evidence of decaying wood in the peat.

\subsection{Geological evidence for the evolution of aquatic ascomycetes}

Freshwater fungi colonise streams around the world, and thus they are not restricted by geographical barriers (Wood-Eggenschwiler and Bärlocher, 1985; Vijaykrishna et al., 2006). Hyde and Goh (2003) suggest that fungi 1) might have evolved before the split of the continents, or 2) have been carried between continents on plant substrates, or 3) fungal spores may have dispersed by animals or wind. Ecological and molecular data suggest that freshwater ascomycetes should have evolved from their terrestrial ancestors (Vijaykrishna et al., 2006) and may have multiple origins (Belliveau and Bärlocher, 2005). Molecular studies propose that the earliest divergence of freshwater species in Jahnulales occurred at $380 \pm 100$ MYA (Paleozoic period), however most of the freshwater lineages appear to have diverged during the Mesozoic period (66-245 MYA) (Vijaykrishna et al., 2006). In contrast, palaeontological studies reveal that fungal diversity increased after the Cretaceous-Tertiary boundary and that fungi underwent rapid specialisation during the Tertiary, connected with the evolution of angiosperms (Graham, 1962; Kalgutkar, 1993, 1997).

In the absence of the molecular data for the evolution of Megalohypha aqua-dulces, palaeontological data reveal the occurrence of Fusiformisporites since the Upper Cretaceous (Fig. 2), corresponding well with the diversification of flowering plants and pointing to a coevolution of both groups. The first description of Fusiformisporites, $F$. crabbii, was made from Upper Cretaceous to the Middle Eocene sediments of the Burrard Formation of western British Columbia (Rouse, 1962). Further Upper Cretaceous finds of Fusiformisporites are known from NW Bolivia (Vajda-Santivanez, 1999), NW Ellesmere Island in Canada (Falcon-Lang et al., 2004) and the north-western desert in Egypt (El Beialy et al., 2010).

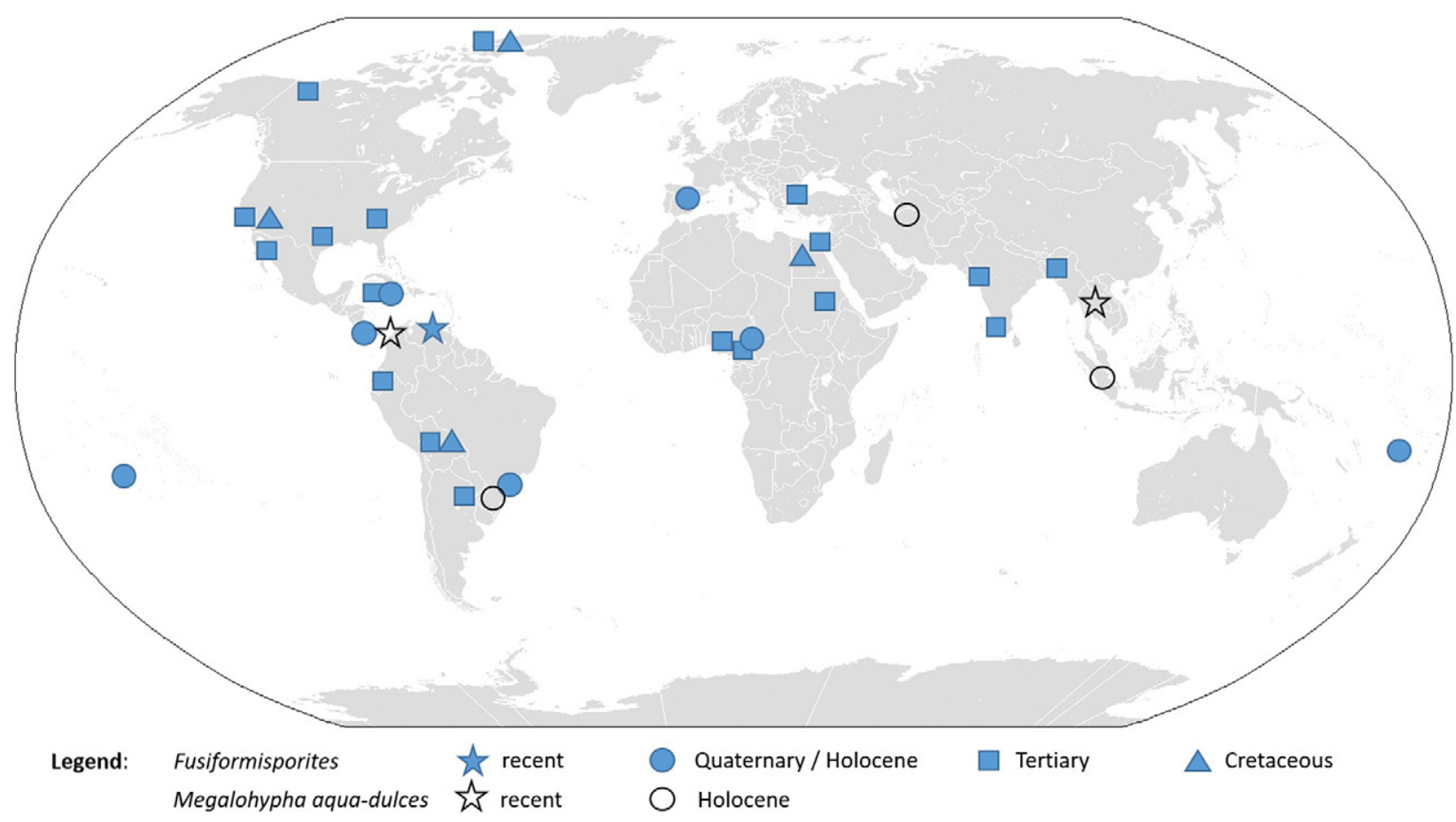

Fig. 2. Recent distribution and geological records of Megalohypha aqua-dulces and Fusiformisporites. 
During the Tertiary, Fusiformisporites evolves further and becomes more diverse and abundant (Fig. 2, Elsik, 1976). In the Paleogene, Fusiformisporites pseudocrabbii, Fusiformisporites crabbii, Fusiformisporites lineolatus, Fusiformisporites lineatus, Fusiformisporites annafrancescae, Fusiformisporites microstriatus, Fusiformisporites paucistriatus, Fusiformisporites rugosus and other Fusiformisporites species are documented in the USA (Elsik, 1968; Sheffy and Dilcher, 1971), Canada (Kalgutkar, 1997; Norris, 1997), coasts of North America (Mustard and Rouse, 1994; Jansonius and Kalgutkar, 2000), Jamaica (Germeraad, 1979), central Ecuador (Jaillard et al., 2004), India (Saxena, 2006; Singh et al., 2011), Northern Trace basin (Turkey) (Ediger and Alișan, 1989), Cameroon (Salard-Cheboldaeff, 1979) and the Ethiopian Plateau (Massini and Jacobs, 2011). Neogene finds of Fusiformisporites are less diverse. Fusiformisporites pseudocrabbii was found in the Eastern Niger Delta in Nigeria (Ajaegwu et al., 2012) and in the Parana Formation of Argentina (Garralla, 1989). Fusiformisporites crabbii is known from the Niger Delta (Bankole et al., 2014) and in Mizoram of NE India (Nandi and Sinha, 2007; Kar et al., 2010). Fusiformisporites acutus is described from the Miocene Quilon Beds of Kerala State in India (Kumar, 1990). Other unidentified Fusiformisporites are documented in the Niger Delta (Oboh, 1992), Cameroon (Tchouatcha et al., 2010), the Gulf of Suez in Egypt (El Beialy et al., 2005), the Gulf of California (Helenes et al., 2009), and India (Singh and Chauhan, 2008).

During the Quaternary, Fusiformisporites was found in the late glacial sediments in southern Brazil (Medeanic and Silva, 2010) as well as in the Holocene sediments of the Changuinola peat deposit in Panama (Phillips, 1995), at Holland bay and Bowden in Jamaica (Germeraad, 1979), SW Pacific islands (Macphail and Stevenson, 2004) and in the late Quaternary - Holocene sediments of Spain (Carrión and van Geel, 1999; Carrión and Navarro, 2002). Rull and Vegas-Villarúbia (1999) found Fusiformisporites in surface samples from a coastal basin in Venezuela. Al-Ameri and Jassim (2011) indicated the presence of Fusiformisporites in the late Quaternary sediments of southern Iraq, but a photo of the hyaline spore does not correspond to Fusiformisporites. In addition, Holocene finds of Fusiformisporites, new records of Megalohypha aqua-dulces are documented for north-eastern Iran, southern Brazil and Indonesia (Fig. 2).

Based on Fusiformisporites, the evolution of Megalohypha aqua-dulces can be traced to the late Cretaceous, defining its divergence within Jahnulales (Vijaykrishna et al., 2006).

\section{Conclusions}

Several species of the form genus Fusiformisporites have been described from Cretaceous to Holocene times (Kalgutkar and Jansonius, 2000). Not all of them seem to fulfil the morphological criteria of the genus Fusiformisporites as erected by Rouse (1962). The type species Fusiformisporites crabbii and the later erected Fusiformisporites annafrancescae, Fusiformisporites keralensis, Fusiformisporites paucistriatus, and Fusiformisporites pseudocrabbii are in close morphological accordance to the extant fungi Megalohypha aqua-dulces (Ferrer et al., 2007). Megalohypha aqua-dulces is a lignicolous freshwater fungus from the tropics belonging to order Jahnulales. Its substrate and habitat preference is underlined by the co-occurrence of spores from additional lignicolous freshwater taxa as Sporoschisma saccardoi-type, Dictyosporium heptasporum, Dictyosporium digitatum, Zopfiella cf. submersa, Xylomyces chlamydosporus-type in the Holocene record from NE Iran (Shumilovskikh et al., 2016). Until now known recent and Holocene finds of Megalohypha aqua-dulces indicate that it can be expected in appropriate habitats of the tropics and subtropics including semi-arid regions. Its evolutionary history reaches back into the late Cretaceous and is most probably associated with the diversification of angiosperms. In the fossil context, Megalohypha aqua-dulces is a good indicator for decaying wood, even if macroremains of trees and shrubs do not appear in the sediment.

\section{Acknowledgements}

We thank James Dalling and Bas van Geel for helpful comments on the manuscript. The study is conducted within the European Research Council project PERSIA (grant 295375) and partly supported by the Russian Foundation for Basic Research (16-35-60083) and the Tomsk State University competitiveness improvement programme (grant 8.1.19.2017).

\section{References}

Ajaegwu, N.E., Odoh, B.I., Akpunonu, E.O., Obiadi, I.I., Anakwuba, E.K., 2012. Late Miocene to early Pliocene palynostratigraphy and palaeoenvironments of ANE-1 Wall, Eastern Niger Delta, Nigeria. J. Min. Geol. 48, 31-43.

Al-Ameri, T.K., Jassim, S.Y., 2011. Environmental changes in the wetlands of Southern Iraq based on palynological studies. Arab. J. Geosci. 4, 443-461.

Bankole, S.I., Schrank, E., Osterloff, P.L., 2014. Palynostratigraphy, palaeoclimates and palaeodepositional environments of the Miocene aged Agbada Formation in the Niger Delta, Nigeria. J. Afr. Earth Sci. 95, 41-62.

Behling, H., Pillar, V., Bauermann, S.G., 2005. Late Quaternary grassland (Campos), gallery forest, fire and climate dynamics, studied by pollen, charcoal and multivariate analysis of the São Francisco de Assis core in western Rio Grande do Sul (southern Brazil). Rev. Palaeobot. Palynol. 133, 235-248.

Belliveau, M.J.-R., Bärlocher, F., 2005. Molecular evidence confirms multiple origins of aquatic hyphomycetes. Mycol. Res. 109, 1407-1417.

Cai, L., Hyde, K.D., Tsui, C.K.M., 2006. Genera of freshwater fungi. Fungal Diversity Research Series 18. Fungal Diversity Press.

Campbell, J., Ferrer, A., Raja, H.A., Sivichai, S., Shearer, C.A., 2007. Phylogenetic relationships among taxa in the Jahnulales inferred from $18 \mathrm{~S}$ and $28 \mathrm{~S}$ nuclear ribosomal DNA sequences. Can. J. Bot. 85, 873-882.

Carrión, J.S., Navarro, C., 2002. Cryptogam spores and other non-pollen microfossils as sources of palaeoecological information: case-studies from Spain. Ann. Bot. Fenn. 39, $1-14$.

Carrión, J.S., van Geel, B., 1999. Fine-resolution Upper Weichselian and Holocene palynological record from Navarrés (Valencia, Spain) and a discussion about factors of Mediterranean forest succession. Rev. Palaeobot. Palynol. 106, 209-236.

Clarke, R.T., 1965. Fungal spores from Vermejo Formation coal beds (Upper Cretaceous) of central Colorado. Mt. Geol. 2, 85-93.

Damon, S.C., 1952. Type studies in Dyctiosporium, Speira, and Cattanea. Lloydia 15, 110-124.

Ediger, V.S., Alișan, C., 1989. Tertiary fungal and algal palynomorph biostratigraphy on the Northern Thrace Basin, Turkey. Rev. Palaeobot. Palynol. 58, 139-161.

El Beialy, S.Y., Mahmoud, M.S., Ali, A.S., 2005. Insights on the age, climate and depositional environments of the Rudeis and Kareem formations, GS-78-1 well, Gulf of Suez, Egypt: a palynological approach. Rev. Esp. Micropaleontol. 37, 273-289.

El Beialy, S.Y., El Atfy, H.S., Zavada, M.S., El Khoriby, E.M., Abu-Zied, R.H., 2010. Palynological, palynofacies, paleoenvironmental and organic geochemical studies on the Upper Cretaceous succession of the GPTSW-7 well, North Western Desert, Egypt. Mar. Pet. Geol. 27, 370-385.

Elsik, W.C., 1968. Palynology of a Paleocene Rockdale lignite, Milam county, Texas. I. Morphology and taxonomy. Pollen Spores 10, 263-314.

Elsik, W.C., 1976. Microscopic fungal remains and cenozoic palynostratigraphy. Geosci. Man 15, 115-120

Elsik, W.C., 1983. Annotated glossary of fungal palynomorphs. AASP Contributions Series 11, pp. 1-42.

Falcon-Lang, H.J., MacRae, R.A., Csank, A.Z., 2004. Palaeoecology of Late Cretaceous polar vegetation preserved in the Hansen Point Volcanics, NW Ellesmere Island, Canada. Palaeogeogr. Palaeoclimatol. Palaeoecol. 212, 45-64.

Ferrer, A., Sivichai, S., Shearer, C.A., 2007. Megalohypha, a new genus in the Jahnulales from aquatic habitats in the tropics. Mycologia 99, 456-460.

Garralla, S., 1989. Palinomorfos (fungi) de la formacion Parana (Mioceno superior) del Pozo Josefina, provincia de Santa Fe, Argentina. Rev. Asoc. Cienc. Nat. Litoral 20, 29-39.

Gelorini, V., Verbeken, A., van Geel, B., Cocquyt, C., Verschuren, D., 2011. Modern non-pollen palynomorphs from East African lake sediments. Rev. Palaeobot. Palynol. 164, 143-173.

Germeraad, J.H., 1979. Fossil remains of fungi, algae and other organisms from Jamaica. Scr. Geol. 52, 1-41.

Goh, T.K., Ho, W.H., Hyde, K.D., Tsui, K.M., 1997a. Four new species of Xylomyces from submerged wood. Mycol. Res. 101, 1323-1328.

Goh, T.K., Ho, W.H., Hyde, K.D., Umali, T.E., 1997b. New records and species of Sporoschisma and Sporoschismopsis from submerged wood in the tropics. Mycol. Res. 101, 1295-1307.

Goh, T.K., Hyde, K.D., Ho, W.H., Yanna, 1999. A revision of the genus Dictyosporium, with descriptions of three new species. Fungal Divers. 2, 65-100.

Goos, R.D., Brooks, R.D., Lamore, B.J., 1977. An undiscribed hyphomycete from wood submerged in a Rhode Island stream. Mycologia 69, 280-286.

Graham, A., 1962. The role of fungal spores in palynology. J. Paleontol. 36, 60-68.

Guarro, J., Al-Saadoon, A.H., Gené, J., Abdullah, S.K., 1997. Two new cleistothecial ascomycetes from Iraq. Mycologia 89, 955-961.

Hawksworth, D.L., Webb, J.A., Wiltshire, P., 2016. Caryospora callicarpa: found in archaeological and modern preparations - but not collected since 1865. Field Mycol. 11, $55-59$. 
Helenes, J., Carreño, A.L., Carrillo, R.M., 2009. Middle to late Miocene chronostratigraphy and development of the northern Gulf of California. Mar. Micropaleontol. 72, 10-25.

Hyde, K.D., Goh, T.K., 2003. Adaptation for dispersal in filamentous freshwater fungi. In: Tsui, C.K.M., Hyde, K.D. (Eds.), Freshwater Mycology. Fungal Diversity Press, Hong Kong, pp. 231-258.

Iturriaga, T., Pfister, D.H., 2006. A monograph of the genus Cookeina (Ascomata, Pezizales, Sarcoscyphaceae). Mycotaxon 95, 137-180.

Jaillard, E., Ordoñez, M., Suárez, J., Toro, J., Iza, D., Lugo, W., 2004. Stratigraphy of the late Cretaceous - paleogene deposits of the Cordillera Occidental of central Ecuador: geodynamic implications. J. S. Am. Earth Sci. 17, 49-58.

Jansonius, J., Kalgutkar, R.M., 2000. Redescription of some fossil fungal spores. Palynology 24, 37-47.

Kalgutkar, R.M., 1993. Paleogene fungal palynomorphs from Bonnet Plume Formation, Yukon Territory. Geol. Surv. Can. Bull. 444, 51-105.

Kalgutkar, R.M., 1997. Fossil fungi from the lower Tertiary Iceberg Bay Formation, Eukeka Sound Group, Axel Heiberg Island, Northwest Territories, Canada. Rev. Palaeobot. Palynol. 97, 197-226.

Kalgutkar, R.M., Jansonius, J., 2000. Synopsis of fossil fungal spores, mycelia and fructifications. AASP Contributions Series 39.

Kar, R., Mandaokar, B.D., Kar, R.K., 2010. Fungal taxa from the Miocene sediments of Mizoram, northeast India. Rev. Palaeobot. Palynol. 158, 240-249.

Klymiuk, A.A., Taylor, T.N., Taylor, E.L., Krings, M., 2013. Paleomycology of the Princeton Chert I. Fossil hyphomycetes associated with the early Eocene aquatic angiosperm, Eorhiza arnoldii. Mycologia 105, 521-529.

Kohlmeyer, J., Volkmann-Kohlmeyer, B., 1998. A new marine Xylomyces on Rhizophora from the Caribbean and Hawaii. Fungal Divers. 1, 159-164.

Kumar, P., 1990. Fungal remains from the Miocene Quilon Beds of Kerala State, South India. Rev. Palaeobot. Palynol. 62, 13-28.

Macphail, M., Stevenson, J., 2004. Fungal Spores in Archaeological Contexts: Part 1: Background Evidence. Centre for Archaeological Research, Canberra.

Malloch, D., Cain, R.F., 1971. New cleistothecial Sordariaceae and a new family, Coniochaetaceae. Can. J. Bot. 49, 869-880.

Marsh, P.E., Cohen, A.D., 2008. Identifying high-level salt marshes using a palynomorphic fingerprint with potential implications for tracking sea level change. Rev. Palaeobot. Palynol. 148, 60-69.

Massini, J.L.G., Jacobs, B.F., 2011. The effects of volcanism on Oligocene-age plant communities from the Ethiopian Plateau, and implications for vegetational resilience in a heterogeneous landscape. Rev. Palaeobot. Palynol. 164, 211-222.

Medeanic, S., Silva, M.B., 2010. Indicative value of non-pollen palynomorphs (NPPs) and palynofacies for paleoreconstructions: Holocene peat, Brazil. Int. J. Coal Geol. 84, 248-257.

Mustard, P.S., Rouse, G.E., 1994. Stratigraphy and evolution of Tertiary Georgia Basin and subjacent Upper Cretaceous sedimentary rocks, southwestern British Columbia and northwestern Washington State. In: Monger, J.W.H. (Ed.), Geology and Geological Hazards of the Vancouver Region, Southwestern British Columbia. Geological Survey of Canada Bulletin 481, pp. 97-169.

Nandi, B., Sinha, A., 2007. Validation of the Miocene fungal spore Mediaverrunites from Mizoram, India. Palynology 31, 95-100.

Norris, G., 1997. Paleocene-Pliocene deltaic to inner shelf palynostratigraphic zonation, depositional environments and paleoclimates in the Imperial ADGO F-28 Well, Beaufort-Mackenzie basin. Geol. Surv. Can. Bull. 523 (71 pp.).

Nuñez Otaño, N., Di Pasquo, M., Bianchinotti, M.V., 2016. The occurrence of Potamomyces palmarensis sp. nov. in the Late Holocene of El Palmar National Park (Colón, Entre Ríos, Argentina) and transfer of fossil species of Mediaverrunites to Potamomyces. Palynology 41, 267-277.

Oboh, F.E., 1992. Multivariate statistical analyses of palynodebris from the Middle Miocene of the Niger Delta and their environmental significance. Palaios 7, 559-573.

Oliveira, M.S., Malosso, E., Barbosa, M.A., Araújo, M.A.G., Castañeda-Ruiz, R.F., 2015. Xylomyces acerosisporus sp. nov. from submerged leaves from Brazil. Mycotaxon $130,875-878$

Phillips, S., 1995. Holocene Evolution of the Changuinola Peat Deposit, Panama: Sedimentology of a Marine-influenced Tropical Peat Deposit on a Tectonically Active Coast. (PhD Thesis). The University of British Columbia.

Pirozynski, K.A., 1989. Methods in Quaternary ecology \#9. Fungi. Geosci. Can. 16, 183-189.
Prager, A., Barthelmes, A., Theuerkauf, M., Joosten, H., 2006. Non-pollen palynomorphs from modern Alder carrs and their potential for interpreting microfossil data from peat. Rev. Palaeobot. Palynol. 141, 7-31.

Rouse, G.E., 1962. Plant microfossils from Burrard Formation of Western British Columbia. Micropaleontology 8, 187-218.

Rull, V., Vegas-Villarúbia, T., 1999. Surface palynology of a small coastal basin from Venezuela and potential paleoecological applications. Micropaleontology 45, 365-393.

Salard-Cheboldaeff, M., 1979. Palynologie maestrichtienne et tertiaire du Cameroun. Etudie qualitative et repartition verticale des principales especes. Rev. Palaeobot. Palynol. 28, 365-388.

Saxena, R.K., 2006. A Catalogue of Tertiary Fungi from India. Birbal Sahni Institute of Palaeobotany, Lucknow.

Schlütz, F., Shumilovskikh, L.S., 2013. On the relation of Potamomyces armatisporus to the fossil form-type Mediaverrunites and its taxonomical and ecological implications. Fungal Ecol. 6, 309-315.

Schlütz, F., Shumilovskikh, L.S., 2017. Non-pollen palynomorphs notes: 1. Type HdV-368 (Podospora-type), description of associated species, and the first key to related spore types. Rev. Palaeobot. Palynol. 239, 47-54.

Sheffy, M.V., Dilcher, D.L., 1971. Morphology and taxonomy of fungal spores. Palaeontogr. Abt. B 133, 34-51.

Sherwood-Pike, M.A., 1988. Freshwater fungi: fossil record and paleoecological potential. Palaeogeogr. Palaeoclimatol. Palaeoecol. 62, 271-285.

Shumilovskikh, L.S., Schlütz, F., Achterberg, I., Bauerochse, A., Leuschner, H.H., 2015. The development of the raised bog "Borsteler Moor" (Lower Saxony, Germany) based on non-pollen palynomorph data. Stud. Quat. 32, 5-18.

Shumilovskikh, L.S., Hopper, K., Djamali, M., Ponel, P., Demory, F., Rostek, F., Tachikawa, K. Bittmann, F., Golyeva, A., Guibal, F., Talon, B., Wang, L.-C., Nezamabadi, M., Bard, E., Lahijani, H., Nokandeh, J., Omrani Rekavandi, H., de Beaulieu, J.-L., Sauer, E. Andrieu-Ponel, V., 2016. Landscape evolution and agro-sylvo-pastoral activities on the Gorgan Plain (NE Iran) in the last 6000 years. The Holocene 26, 1676-1691.

Simonis, J.L., Raja, Huzefa A., Shearer, C.A., 2008. Extracellular enzymes and soft rot decay: are ascomycetes important degraders in fresh water? Fungal Divers. 31, 135-146.

Singh, S.K., Chauhan, M.S., 2008. Fungal remains from the Neogene sediments of Mahuadanr valley, Latehar district, Jharkhand, India and their palaeoclimatic significance. J. Palaeontol. Soc. India 53, 73-81.

Singh, S.D., Sinha, S., Shukla, S., Gupta, A., Shanmukhappa, M., 2011. Refinement of paleobathymentric curves of paleocene - early eocene sequences in selected wells of Cambay Basin. Abstract Proceeding. The 2nd South Asian Geoscience Conference and Exhibition, Geolndia2011.

Sivichai, S., Sri-indrasudthi, V., Gareth Jones, E.B., 2011. Jahnula aquatica and its anamorph Xylomyces chlamidosporus on submerged wood in Thailand. Mycotaxon 116 137-142.

Suetrong, S., Boonyuen, N., Pang, K.-L., Ueapattanakit, J., Klaysuban, A., Sri-indrasutdhi, V. Sivichai, S., Jones, E.B.G., 2011. A taxonomic revision and phylogenetic reconstruction of the Jahnulales (Dothideomycetes), and the new family Manglicolaceae. Fungal Divers. $51,163-188$

Taylor, T.N., Krings, M., Taylor, E.L., 2015. Fossil fungi. Elsevier, Amsterdam.

Tchouatcha, S.M., Ricard, N.N.P., Salah, M.M., Said, D.A., Ekodeck, E.G., 2010. Existence of "late continental" deposits in the Mbere and Djerem sedimentary basins (North Cameroon): palynologic and stratigraphic evidence. J. Geol. Min. Res. 2, 159-169.

Vajda-Santivanez, V., 1999. Miospores from upper Cretaceous - paleocene strata in northwestern Bolivia. Palynology 23, 181-196.

Van Geel, B., Aptroot, A., 2006. Fossil ascomycetes in Quaternary deposits. Nova Hedwigia 82, 313-329.

Van Geel, B., Gelorini, V., Lyaruu, A., Aptroot, A., Rucina, S., Marchant, R., Sinninghe Damsté, J.S., Verschuren, D., 2011. Diversity and ecology of tropical African fungal spores from a 25,000-year palaeoenvironmental record in southeastern Kenya. Rev. Palaeobot. Palynol. 164, 174-190.

Vijaykrishna, D., Jeewon, R., Hyde, K.D., 2006. Molecular taxonomy, origins and evolution of freshwater ascomycetes. Fungal Divers. 23, 351-390.

Weinstein, R.N., Pfister, D.H., Iturriaga, T., 2002. A phylogenetic study of the genus Cookeina. Mycologia 94, 673-682.

Wolf, F.A., 1967. Fungus spores in east African lake sediments. Mycologia 59, 397-404

Wood-Eggenschwiler, S., Bärlocher, F., 1985. Geographical distribution of Ingoldian fungi. Verh. Int. Ver. Theor. Angew. Limnol. 22, 2780-2785. 